\title{
Influence of cow or goat milk consumption on antioxidant defence and lipid peroxidation during chronic iron repletion
}

\author{
Javier Díaz-Castro ${ }^{1 *}$, Luis J. Pérez-Sánchez ${ }^{1}$, Mercedes Ramírez López-Frías ${ }^{1}$, \\ Inmaculada López-Aliaga ${ }^{1}$, Teresa Nestares ${ }^{1}$, María J. M. Alférez ${ }^{1}$, M. Luisa Ojeda ${ }^{2}$ and \\ Margarita S. Campos ${ }^{1}$ \\ ${ }^{1}$ Department of Physiology, Faculty of Pharmacy, Institute of Nutrition and Food Technology, Campus Universitario \\ de Cartuja, University of Granada, Granada 18071, Spain \\ ${ }^{2}$ Department of Physiology and Zoology, Faculty of Pharmacy, University of Seville, Seville 41012, Spain
}

(Submitted 23 June 2011 - Final revision received 10 August 2011 - Accepted 23 August 2011 - First published online 30 September 2011)

\section{Abstract}

Despite Fe deficiency and overload having been widely studied, no studies are available about the influence of milk consumption on antioxidant defence and lipid peroxidation during the course of these highly prevalent cases. The objective of the present study was to assess the influence of cow or goat milk-based diets, either with normal or Fe-overload, on antioxidant defence and lipid peroxidation in the liver, brain and erythrocytes of control and anaemic rats after chronic Fe repletion. Weanling male rats were randomly divided into two groups: a control group receiving a normal-Fe diet $(45 \mathrm{mg} / \mathrm{kg})$ and an anaemic group receiving a low-Fe diet $(5 \mathrm{mg} / \mathrm{kg})$ for $40 \mathrm{~d}$. Control and anaemic rats were fed goat or cow milk-based diets, either with normal Fe or Fe-overload ( $450 \mathrm{mg} / \mathrm{kg}$ ), for 30 or $50 \mathrm{~d}$. Fe-deficiency anaemia did not have any effect on antioxidant enzymes or lipid peroxidation in the organs studied. During chronic Fe repletion, superoxide dismutase (SOD) activity was higher in the group of animals fed the cow milk diet compared with the group consuming goat milk. The slight modification of catalase and glutathione peroxidise activities in animals fed the cow milk-based diet reveals that these enzymes are unable to neutralise and scavenge the high generation of free radicals produced. The animals fed the cow milk diet showed higher rates of lipid peroxidation compared with those receiving the goat milk diet, which directly correlated with the increase in SOD activity. It was concluded that goat milk has positive effects on antioxidant defence, even in a situation of Fe overload, limiting lipid peroxidation.

\section{Key words: Cow milk: Goat milk: Antioxidant enzymes: Lipid peroxidation: Chronic iron repletion}

Fe is an essential micronutrient, required for adequate erythropoietic function, oxidative metabolism, enzymatic activities and cellular immune responses ${ }^{(1)}$. Increased Fe requirements, limited dietary supply and blood loss may lead to Fe-deficiency anaemia $^{(2)}$. In addition, the same properties that make Fe essential also make this element potentially harmful; in excess, Fe is highly toxic due to its ability to form highly dangerous reactive oxygen species, and it has been implicated in several pathological conditions $^{(3,4)}$. The physiological functions and the integrity of the cellular structures can be altered due to the reactivity of these free radicals. The organism has an enzymatic machinery that works to eliminate and neutralise these harmful species. In several pathological conditions, the balance between pro-oxidants and antioxidants can be altered depending on the oxidative stress as well as on the system of antioxidant defence ${ }^{(5-8)}$.

On the other hand, antioxidant defence depends not only on dietary Fe concentrations, but also on the type, amount and quality of fat in the diet ${ }^{(9)}$. Our research group has previously reported that goat milk fat has a higher nutritional quality than cow milk fat ${ }^{(10)}$ and improves Fe metabolism ${ }^{(11)}$. Nevertheless, in the scientific literature, to date, no studies are available about the influence of goat milk consumption on antioxidant defence mechanisms and lipid peroxidation.

Therefore, the present study was carried out to assess the effect of cow or goat milk-based diets, either with normal Fe content or Fe-overload, on the antioxidant defence and lipid peroxidation of control and anaemic rats, during the course of chronic $\mathrm{Fe}$ repletion in animals with experimentally induced Fe-deficiency anaemia.

\section{Materials and methods}

\section{Animals}

All animal care procedures and experimental protocols were approved by the Ethics Committee of the University of

Abbreviations: CAT, catalase; GPx, glutathione peroxidase; SOD, superoxide dismutase; TBARS, thiobarbituric acid-reactive substances; TIBC, total ironbinding capacity.

*Corresponding author: J. Díaz-Castro, fax +34958 248959, email javierdc@ugr.es 
Granada in accordance with the European Community guidelines. A total of 184 male Wistar albino breed rats (21 d of age and weighing about $40-47 \mathrm{~g}$ ), purchased from the University of Granada Laboratory Animal Service (Granada, Spain), were used in the present study.

\section{Experimental design}

At the beginning of the study, rats were divided into two groups: a control group receiving a normal-Fe diet $(44.7 \mathrm{mg} / \mathrm{kg}$ by analysis) ${ }^{(12)}$ and an anaemic group receiving a low-Fe diet $(6.3 \mathrm{mg} / \mathrm{kg}$ by analysis). Anaemia was induced experimentally during $40 \mathrm{~d}$ by a technique developed previously by us ${ }^{(13)}$

During the course of the study, animals were kept at an automatically controlled temperature $\left(22-23^{\circ} \mathrm{C}\right)$, humidity (55-65\%) and a $12 \mathrm{~h}$ light-12h dark cycle (09.00-21.00 hours). Diet intake was controlled, pair-feeding all animals ( $80 \%$ of the average intake) and double-distilled water was available ad libitum. On day 40 of the study, twelve rats per group ( $n 12$ for the control group and $n 12$ for the anaemic group) were anaesthetised by intraperitoneal injection with sodium pentobarbital (Sigma Diagnostics, St Louis, MO, USA), totally bled out and blood aliquots with EDTA were analysed to measure haematological parameters; other blood samples were centrifuged $\left(1500 \mathrm{~g}, 4^{\circ} \mathrm{C}, 15 \mathrm{~min}\right)$ to measure thiobarbituric acid-reactive substances (TBARS) and superoxide dismutase (SOD) activity. The remaining blood sample was centrifuged without anticoagulant to separate erythrocytes from the serum and for subsequent analysis of Fe, ferritin and total iron-binding capacity (TIBC). Liver and brain were removed and washed with ice-cold saline solution (0.9\%, $\mathrm{w} / \mathrm{v}, \mathrm{NaCl}$ ). Liver, brain and erythrocyte cytosolic fractions were freshly prepared the same day by successive differential centrifugations with hypotonic haemolysis according to the method of Hanahan \& Ekholm ${ }^{(14)}$, preserving these cytosolic fractions at $-80^{\circ} \mathrm{C}$ for further analyses of antioxidant enzymes, catalase (CAT) and glutathione peroxidase (GPx). Protein contents in the cytosolic fractions were measured following the method described by Lowry et al. ${ }^{(15)}$

After the induction of anaemia (day 40 of the study), the remaining animals ( $n$ 160) were then placed on an experimental period in which the control and anaemic groups were further fed for 30 or $50 \mathrm{~d}$ with cow or goat milk-based diet, either with normal Fe content $(45 \mathrm{mg} / \mathrm{kg})$ or Fe-overload $(450 \mathrm{mg} / \mathrm{kg})$, to induce chronic Fe overload ${ }^{(16)}$. The milkbased diets were prepared with skimmed cow (Holstein breed) or goat milk (Murciano-granadina breed) powder (20\% protein) and 10\% fat, obtained by purification from cow or goat milk fat. Fe contents in the diets by analysis were as follows: normal-Fe diet $-41.6 \mathrm{mg} / \mathrm{kg}$ (cow milkbased diet) and $42.3 \mathrm{mg} / \mathrm{kg}$ (goat milk-based diet); Fe-overloaded diets - $471.0 \mathrm{mg} / \mathrm{kg}$ (cow milk-based diet) and $473.2 \mathrm{mg} / \mathrm{kg}$ (goat milk-based diet).

On days 70 and 90 of the study, animals were totally bled out by cannulation of the abdominal aorta ( $n 80$ on day 70 and $n 80$ on day 90) and plasma was obtained for TBARS determination. The remaining blood sample was collected to obtain serum and separate erythrocytes; later, liver and brain were also removed. Liver, brain and erythrocyte cytosolic fractions were freshly prepared and SOD, CAT and GPX activities were subsequently measured as described previously (day 40 of the study).

\section{Iron determination in the diets}

After mineralisation by a wet method in a sand bath (J.R. Selecta, Barcelona, Spain), Fe concentrations in the experimental diets were determined by atomic absorption spectrophotometry (PerkinElmer Analyst 1100B spectrometer with WinLab32 for AA software; PerkinElmer, Ueberlingen, Germany). To calibrate the measurements, samples of lyophilised bovine liver (certified reference material BCR 185; Community Bureau of References, Brussels, Belgium) were used to determine Fe recovery $(\mathrm{Fe}$ value $=210(\mathrm{SEM} 5 \cdot 8) \mathrm{mg} / \mathrm{kg}$, means with their standard errors of the mean of five determinations, certified value $=214(\operatorname{sem} 5 \cdot 0) \mathrm{mg} / \mathrm{kg})$.

\section{Haematological test}

All the haematological parameters studied were measured using an automated haematology analyser (Sysmex K-1000D; Sysmex, Tokyo, Japan).

\section{Serum ferritin}

Serum ferritin concentration was determined using the Rat Ferritin ELISA Kit (Biovendor Gmbh, Heidelberg, Germany). The absorbance of the reaction was read at $450 \mathrm{~nm}$ using a microplate reader (Bio-Rad Laboratories, Inc., Hercules, CA, USA). Colour intensity developed was inversely proportional to the concentration of serum ferritin.

\section{Serum iron, total iron-binding capacity and transferrin saturation}

To calculate the rate of transferrin saturation, serum Fe concentration and TIBC were determined using Sigma Diagnostics Iron and TIBC reagents (Sigma Diagnostics). The absorbance of samples was read at $550 \mathrm{~nm}$ on a microplate reader (Bio-Rad Laboratories Inc.). The percentage of transferrin saturation was calculated from the following equation:

Transferrin saturation (\%)

$=$ serum Fe concentration $(\mu \mathrm{g} / \mathrm{l}) / \mathrm{TIBC}(\mu \mathrm{g} / \mathrm{l}) \times 100$.

\section{Antioxidant enzyme activity in the cytosolic fractions of liver, brain and erythrocytes}

GPx activity was measured by the method of Flohé \& Günzler ${ }^{(17)}$, which is based on the formation of oxidised glutathione catalysed by GPx. Oxidised glutathione is reduced by an excess of glutathione reductase and NADPH. The subsequent oxidation of NADPH to $\mathrm{NADP}^{+}$was monitored 
spectrophotometrically (Thermo Spectronic, Rochester, NY, USA) at $340 \mathrm{~nm}$. Cumen hydroperoxide was used as the substrate for the reaction. SOD activity was determined according to the method of Crapo et al. ${ }^{(18)}$, based on its inhibition in the reduction of cytochrome $c$, measured in a spectrophotometer (Thermo Spectronic) at $550 \mathrm{~nm}$. In this sense, one unit of SOD activity is defined as the amount of enzyme required to produce $50 \%$ inhibition of the rate of reduction of cytochrome c. CAT activity was determined following the method described by Aebi ${ }^{(19)}$, monitoring at $240 \mathrm{~nm}$ in a spectrophotometer (Thermo Spectronic) the $\mathrm{H}_{2} \mathrm{O}_{2}$ decomposition, as a consequence of the catalytic activity of CAT. The activity was calculated from the first-order rate constant $K(1 / \mathrm{s})$.

\section{Thiobarbituric acid-reactive substances measurement}

The extent of lipid peroxidation was evaluated on plasma by measuring the concentration of TBARS according to the methods of Yagi ${ }^{(20)}$ and Ohkawa et al. ${ }^{(21)}$. The reaction product was measured by spectrophotometric analysis (Thermo Spectronic) at $532 \mathrm{~nm}$. The assay was calibrated using tetraethoxypropanone (Sigma-Aldrich, Taufkirchen, Germany) as a malondialdehyde source. The results are expressed as nmol TBARS/mg protein.

\section{Statistical analysis}

Differences between the control and anaemic groups were tested for statistical significance with Student's $t$ test. Variance analysis by one-way ANOVA methods was used to compare the different diets supplied to the animals. Individual means were tested by pairwise comparison with Tukey's multiple comparison test when the main effects and their interactions were significant. The level of significance was set at $P<0 \cdot 05$. All data are reported as mean values with their standard errors.

\section{Results and discussion}

After Fe deprivation $(5 \mathrm{mg} / \mathrm{kg}$ of diet) during $40 \mathrm{~d}$, all the haematological parameters in the anaemic group were different from their counterpart control group, due to progressive $\mathrm{Fe}$ depletion from body stores. The haematological parameters in control rats were as follows: serum Fe 1370 (SEM 120) $\mu \mathrm{g} / \mathrm{l}$; $\mathrm{Hb}$ concentration $125 \cdot 5$ (SEM $2 \cdot 4$ ) g/l; erythrocytes $7 \cdot 0$ (SEM $0 \cdot 16) \times 10^{12} / 1$; haematocrit $39 \cdot 2(\operatorname{sem} 0 \cdot 77) \%$; mean corpuscular volume (MCV) 55.5 (SEM 0.2) fl; serum ferritin 82.6 (SEM 2.6) $\mu \mathrm{g} / 1$; transferrin saturation $47 \cdot 1$ (SEM 7.0) \%; platelets 735 $(\operatorname{sem} 25 \cdot 5) \times 10^{9} / 1$; TIBC $2825(\operatorname{sem} 199) \mu \mathrm{g} / \mathrm{l}$. In the anaemic group, the haematological parameters were as follows: serum Fe 710 (SEM 57) $\mu \mathrm{g} / \mathrm{l}$; Hb concentration 74.9 (SEM $2 \cdot 2) \mathrm{g} / \mathrm{l}$; erythrocytes $6.19(\mathrm{SEM} 0 \cdot 19) \times 10^{12} /$; haematocrit $27 \cdot 1(\operatorname{sem} 0 \cdot 44) \% ; \operatorname{MCV} 39 \cdot 2(\operatorname{sem} 0 \cdot 6) \mathrm{fl}$; serum ferritin $50 \cdot 3$ (SEM 1.3) $\mu \mathrm{g} / \mathrm{l}$; transferrin saturation 3.6 (SEM 0.3 ) \%; platelets $1354($ sem 65.6$) \times 10^{9} / 1$; TIBC $17787($ sem 735) $\mu \mathrm{g} / 1$. All these parameters were statistically different between control and anaemic rats $(P<0 \cdot 001)$. Taking into account the long-term Fe restriction in the diet, all these findings were expected and feature the severe Fe deficiency induced.

\section{Antioxidant enzymatic defence during iron deficiency}

Under our experimental conditions, Fe deficiency had no influence on enzymatic mechanisms of antioxidant defence and lipid peroxidation at day 40 of the study. Several authors
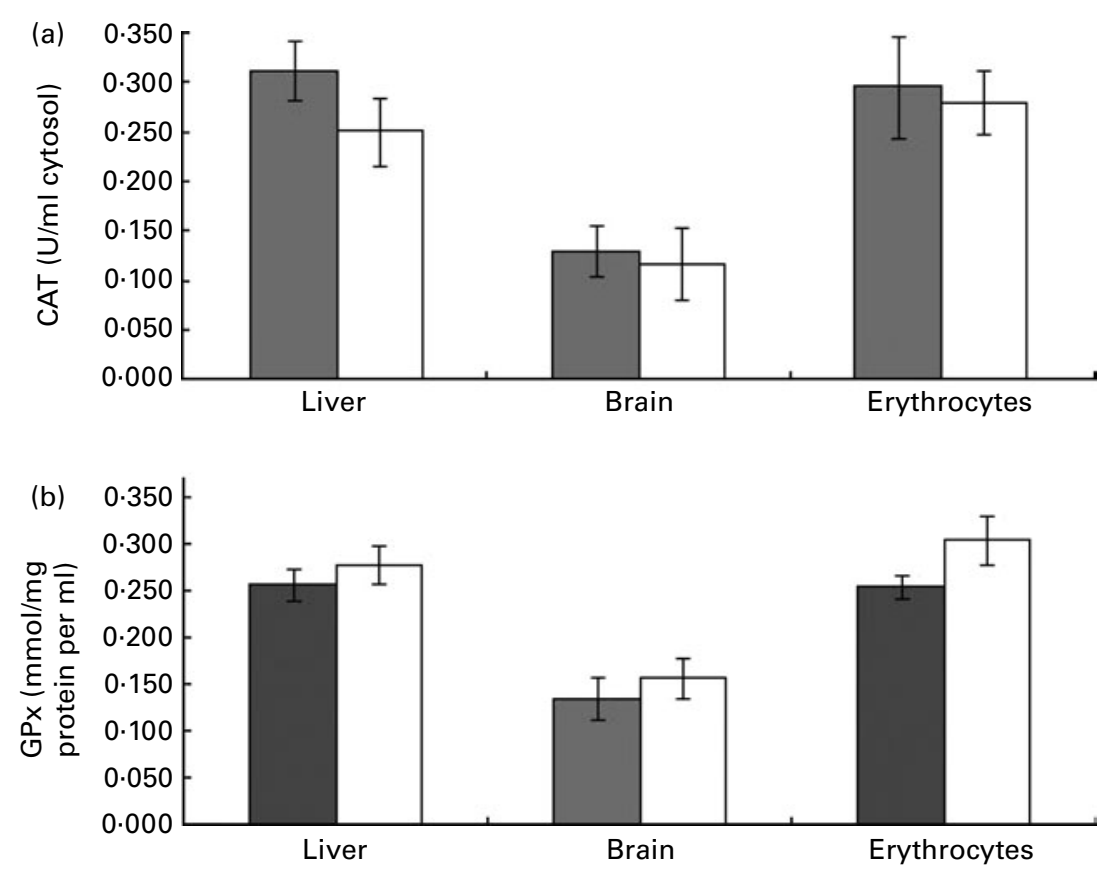

Fig. 1. (a) Catalase (CAT) and (b) glutathione peroxidase (GPx) activity in the liver, brain and erythrocyte cytosolic fractions of control ( $\square$ ) and anaemic ( $\square$ ) rats fed a normal-iron or a low-iron diet during anaemia induction. Values are means, with their standard errors represented by vertical bars. The data were analysed by Student's $t$ test with repeated measures and no differences between the groups were found. 
have stated that GPx activity and TBARS in the case of anaemia are similar to that of normal cells ${ }^{(8,22,23)}$, which coincides with the results obtained in the present study.

The drastic decrease in serum Fe found in anaemic rats at the end of the anaemia induction period $(P<0 \cdot 001)$ involves a minor Fe trafficking in the organism, diminishing the production of free radicals via Fenton and Haber-Weiss chemistry $^{(24)}$, which can explain why SOD activity in plasma is within normal levels in Fe-deficient animals (2.62 (SEM $0 \cdot 23) \mathrm{U} / \mathrm{mg}$ protein in control and $2 \cdot 36$ (SEM $0 \cdot 25$ ) $\mathrm{U} / \mathrm{mg}$ protein in anaemic animals). CAT is a ferric enzyme containing the haem group; therefore, Fe deficiency could impair the activity of Fe-dependent enzymes ${ }^{(25)}$. Nevertheless, under our experimental conditions, CAT activity (Fig. 1(a)) in anaemic rats was not modified with respect to their counterpart control group, probably as a result of a compensatory mechanism, in which, in spite of there being less Fe available to act as a cofactor in the enzymatic molecule, the generation of free radicals is lower due to dietary Fe restriction; therefore, the resultant net antioxidant activity did not have any modification. In addition, SOD, CAT (Fig. 1(a)) and GPX (Fig. 1(b)) are involved in the reduction of harmful peroxides that can damage PUFA, preventing lipid peroxidation; therefore, TBARS levels in plasma did not differ in both experimental groups $(3.12$ (SEM 0.53$) \mathrm{nmol} / \mathrm{mg}$ protein in the control group and $3.20(\operatorname{sem} 0.45) \mathrm{nmol} / \mathrm{mg}$ protein in the anaemic group).

\section{Antioxidant enzymatic defence during chronic iron repletion with milk-based diets}

As a result of the regular cell metabolism, the anion superoxide $\left(\mathrm{O}_{2}^{--}\right)$is converted into $\mathrm{H}_{2} \mathrm{O}_{2}$ by the ubiquitous enzyme SOD. Later, $\mathrm{H}_{2} \mathrm{O}_{2}$ produced in this reaction is converted into harmless compounds by the activities of CAT and GPx; therefore, SOD is the first line of enzymatic defence against free radicals ${ }^{(26)}$. The increased activity of SOD in the groups fed the cow milk-based diet reveals that these animals feature a higher generation of radicals $\mathrm{O}_{2}^{--}$than those fed the goat milk-based diet, either with normal Fe content or Fe overload $(P<0 \cdot 001)$, in all the organs studied (Table 1$)$, which indicates an increase in the production of $\mathrm{H}_{2} \mathrm{O}_{2}$, directly correlated with the rate of neutralisation of radicals $\mathrm{O}_{2}^{--(27)}$. Alférez et al. ${ }^{(28)}$ and Díaz-Castro et $a l .{ }^{(29)}$ demonstrated that goat milk consumption improves $\mathrm{Zn}$ bioavailability, a mineral with antioxidant capacity ${ }^{(30)}$. In addition, this type of milk has a better lipid quality than cows' milk ${ }^{(10)}$; therefore, the generation of free radicals is lower when goat milk is supplied, in comparison with cows' milk, which can be linked to the higher rate of lipid peroxidation achieved in animals fed cows' milk, as will be discussed later. It is also noteworthy that anaemia does not have an influence in the activity of SOD during Fe repletion because, as it has been previously mentioned, Fe deficiency induces modifications in Fe homeostasis, decreasing mitochondrial aconitase activity and preventing the mitochondrial release of oxidants ${ }^{(31)}$.

Table 1. Superoxide dismutase ( $\mathrm{U} / \mathrm{mg}$ protein) in the cytosolic fractions of liver, brain and erythrocytes from control and anaemic rats fed the cow or goat milk-based diets, with normal iron content or iron overload, on days 70 and 90 of the study

(Mean values with their standard errors)

\begin{tabular}{|c|c|c|c|c|c|c|c|c|c|c|c|}
\hline \multirow{3}{*}{$\begin{array}{l}\text { Day of the study, tissue and } \\
\text { Fe content in the diet }\end{array}$} & \multicolumn{4}{|c|}{ Cow milk-based diet $(n 80)$} & \multicolumn{4}{|c|}{ Goat milk-based diet ( $n$ 80) } & & & \\
\hline & \multicolumn{2}{|c|}{$\begin{array}{l}\text { Control group } \\
\quad(n 40)\end{array}$} & \multicolumn{2}{|c|}{$\begin{array}{l}\text { Anaemic group } \\
\quad(n 40)\end{array}$} & \multicolumn{2}{|c|}{$\begin{array}{l}\text { Control group } \\
\quad(n 40)\end{array}$} & \multicolumn{2}{|c|}{$\begin{array}{l}\text { Anaemic group } \\
\qquad(n 40)\end{array}$} & \multicolumn{3}{|c|}{$P$ (one-way ANOVA) } \\
\hline & Mean & SEM & Mean & SEM & Mean & SEM & Mean & SEM & Diet & Anaemia & Fe overload \\
\hline \multicolumn{12}{|l|}{ Liver } \\
\hline \multicolumn{12}{|l|}{ Day 70} \\
\hline Normal Fe & $14.009^{a}$ & 0.450 & $13 \cdot 013^{A}$ & 0.863 & $2 \cdot 227^{b}$ & 0.936 & $2 \cdot 810^{\mathrm{B}}$ & 0.292 & $<0.001$ & NS & \multirow[b]{2}{*}{$<0.05$} \\
\hline Fe overload & $15 \cdot 430^{\mathrm{a}}$ & 0.576 & $15 \cdot 366^{A *}$ & 0.335 & $3 \cdot 285^{\mathrm{b}}$ & 0.421 & $3 \cdot 162^{\mathrm{B}}$ & 0.398 & $<0.001$ & NS & \\
\hline \multicolumn{12}{|l|}{ Day 90} \\
\hline Normal Fe & $14.864^{\mathrm{a}}$ & 0.671 & $13.509^{A}$ & 0.390 & $4.439^{\mathrm{b}}$ & 0.536 & $4.334^{\mathrm{B}}$ & 0.385 & $<0.001$ & NS & \multirow[b]{2}{*}{$<0.001$} \\
\hline Fe overload & $15 \cdot 997^{\mathrm{a}}$ & 0.331 & $15.566^{A}$ & 0.506 & $8.527^{\mathrm{b} *}$ & 0.507 & $8 \cdot 545^{\mathrm{B} *}$ & 0.472 & $<0.001$ & NS & \\
\hline \multicolumn{12}{|l|}{ Brain } \\
\hline Day 70 & & & & & & & & & & & \multirow[b]{3}{*}{ NS } \\
\hline Normal Fe & $9 \cdot 320^{\mathrm{a}}$ & 0.418 & $9.311^{\mathrm{A}}$ & 0.536 & $2 \cdot 914^{\mathrm{b}}$ & 0.313 & $2 \cdot 870^{\mathrm{B}}$ & 0.492 & $<0.001$ & NS & \\
\hline Fe overload & $10 \cdot 534^{a}$ & 1.248 & $10.544^{\mathrm{A}}$ & 1.142 & $3 \cdot 061^{b}$ & 0.543 & $3 \cdot 156^{\mathrm{B}}$ & 0.385 & $<0.001$ & NS & \\
\hline \multicolumn{12}{|l|}{ Day 90} \\
\hline Normal Fe & $12 \cdot 357^{\mathrm{a}}$ & 0.866 & $12 \cdot 264^{A}$ & 0.519 & $8 \cdot 767^{b}$ & 0.810 & $8.539^{B}$ & 0.525 & $<0.001$ & NS & \multirow[b]{2}{*}{ NS } \\
\hline Fe overload & $11.595^{\mathrm{a}}$ & 0.404 & $12 \cdot 745^{A}$ & 1.086 & $8 \cdot 203^{b}$ & 0.308 & $8.765^{\mathrm{B}}$ & 0.570 & $<0.001$ & NS & \\
\hline \multicolumn{12}{|l|}{ Erythrocytes } \\
\hline Day 70 & & & & & & & & & & & \multirow[b]{3}{*}{ NS } \\
\hline Normal $\mathrm{Fe}$ & $12.094^{a}$ & 0.589 & $10.356^{A} t$ & 0.462 & $2 \cdot 823^{b}$ & 0.484 & $2.972^{\mathrm{B}}$ & 0.396 & $<0.001$ & $<0.05$ & \\
\hline Fe overload & $13 \cdot 497^{a}$ & 0.352 & $12 \cdot 836^{A *}$ & 0.452 & $3.677^{b}$ & 0.323 & $3 \cdot 725^{\mathrm{B}}$ & 0.239 & $<0.001$ & NS & \\
\hline \multicolumn{12}{|l|}{ Day 90} \\
\hline Normal Fe & $12 \cdot 843^{a}$ & 0.443 & $12.035^{\mathrm{A}}$ & 0.675 & $8.042^{b}$ & 0.441 & $8.636^{\mathrm{B}}$ & 0.331 & $<0.001$ & NS & \multirow[b]{2}{*}{$<0.05$} \\
\hline Fe overload & $17.860^{a *}$ & 0.656 & $13.716^{\mathrm{A}}$ & 0.609 & $8 \cdot 876^{\mathrm{b}}$ & 0.516 & $8 \cdot 718^{\mathrm{B}}$ & 0.390 & $<0.001$ & NS & \\
\hline
\end{tabular}

a,b Mean values within a row with unlike superscript letters were significantly different among the groups of control rats $(P<0.05 ;$ Tukey's test).

A,B Mean values within a row with unlike superscript letters were significantly different among the groups of anaemic rats $(P<0.05 ;$ Tukey's test)

${ }^{*}$ Mean values were significantly different for the corresponding group of rats fed with normal Fe content $(P<0.05$; Student's $t$ test).

$\dagger$ Mean values were significantly different for the corresponding group of control rats $(P<0.05$; Student's $t$ test). 
The slightly modified activity of CAT (Table 2) and GPx (Table 3) in animals fed the cow milk based-diet indicates that the remarkable increase observed in SOD, which is shown to be connected to an increment of the formation of hydroperoxides and CAT and GPx, is insufficient to neutralise and scavenge this high output of $\mathrm{H}_{2} \mathrm{O}_{2}{ }^{(26)}$. Fe overload increases the production of reactive oxygen species, which is linked to the higher levels of SOD in order to remove the excessive production of $\mathrm{O}_{2}^{--}$. The lower levels of GPx found in the liver and erythrocytes in a situation of Fe overload could be due to the reduction of the enzyme in the process of neutralisation of free radicals generated in animals fed the cow milk-based diet.

The liver is an organ particularly vulnerable to oxidative stress, which is reflected in the increase in SOD activity in hepatic cytosol (Table 1), since the consumption of diets with high Fe content leads to chronic overload ${ }^{(32-35)}$, which produces a high expression of hepcidin. This overexpression of hepcidin controls the Fe levels, directly acting reciprocally with ferroportin 1 , driving to the internalisation and degradation of ferroportin 1 when Fe levels are high, consequently blocking the liberation of $\mathrm{Fe}$ in the hepatocytes and making high concentrations of Fe accumulate in this $\operatorname{organ}^{(36,37)}$. This hepatic Fe overload promotes the generation of free radicals; therefore, the up-regulation of SOD would be used to neutralise this high rate of generation of reactive oxygen species.
The organism does not possess any totally effective way of excreting Fe; therefore, the regulation of the absorption of this mineral in the duodenum plays a critical role in its homeostasis $^{(38)}$. The Fe released in the circulation is bound to transferrin and is transported to the use (mainly erythroid system) and storage (liver) organs. Under our experimental conditions, the erythrocyte is a cell type with some unique features that seems to be affected by Fe overload. An increase in SOD activity was observed in the control group fed the cow milkbased diet $(P<0 \cdot 001)$ in all organs (Table 1$)$, and a decrease in GPx activity $(P<0 \cdot 001$; Table 3$)$ was recorded in control and anaemic animals. This finding indicates that the increase observed in SOD activity induces a concomitant augmentation in the formation of hydroperoxides and CAT is unable to scavenge these reactive oxygen species, needing an increase in GPx activity to remove the excess of these intermediary products highly harmful to the cells ${ }^{(26)}$. The lower levels of GPX in all the groups fed the Fe-overloaded diets found in the present study can be due to the reduction of the enzyme in the process of neutralisation of free radicals generated, as mentioned previously. The beneficial nutritional characteristics of goats' milk can explain the lower effect in the erythrocytes induced by the Fe overload in animals fed this type of diet.

$\mathrm{Fe}$ is a necessary cofactor in many metabolic processes in the central nervous system, including oxidative phosphorylation, myelin synthesis, neurotransmitter production, NO metabolism and oxygen transport. It plays an important role in electron transfer and is a cofactor for a large number of

Table 2. Catalase $(\mathrm{U} / \mathrm{ml}$ cytosol) in the cytosolic fractions of liver, brain and erythrocytes from control and anaemic rats fed the cow or goat milk-based diets, with normal iron content or iron overload, on days 70 and 90 of the study

(Mean values with their standard errors)

\begin{tabular}{|c|c|c|c|c|c|c|c|c|c|c|c|}
\hline \multirow{3}{*}{$\begin{array}{l}\text { Day of the study, tissue and } \\
\text { Fe content in the diet }\end{array}$} & \multicolumn{4}{|c|}{ Cow milk-based diet $(n 80)$} & \multicolumn{4}{|c|}{ Goat milk-based diet ( $n 80)$} & & & \\
\hline & \multicolumn{2}{|c|}{$\begin{array}{l}\text { Control group } \\
\quad(n 40)\end{array}$} & \multicolumn{2}{|c|}{$\begin{array}{l}\text { Anaemic group } \\
\quad(n 40)\end{array}$} & \multicolumn{2}{|c|}{$\begin{array}{l}\text { Control group } \\
\quad(n 40)\end{array}$} & \multicolumn{2}{|c|}{$\begin{array}{l}\text { Anaemic group } \\
\qquad(n 40)\end{array}$} & \multicolumn{3}{|c|}{$P$ (one-way ANOVA) } \\
\hline & Mean & SEM & Mean & SEM & Mean & SEM & Mean & SEM & Diet & Anaemia & Fe overload \\
\hline \multicolumn{12}{|l|}{ Liver } \\
\hline \multicolumn{12}{|l|}{ Day 70} \\
\hline Normal Fe & 0.216 & 0.036 & 0.220 & 0.030 & 0.178 & 0.034 & 0.182 & 0.040 & NS & NS & \multirow{2}{*}{ NS } \\
\hline Fe overload & 0.314 & 0.086 & 0.254 & 0.087 & 0.206 & 0.021 & 0.216 & 0.053 & NS & NS & \\
\hline \multicolumn{12}{|l|}{ Day 90} \\
\hline Normal Fe & 0.257 & 0.027 & 0.260 & 0.035 & 0.273 & 0.050 & 0.278 & 0.040 & NS & NS & \multirow[b]{2}{*}{ NS } \\
\hline Fe overload & 0.320 & 0.033 & 0.337 & 0.037 & 0.337 & 0.066 & 0.329 & 0.024 & NS & NS & \\
\hline \multicolumn{12}{|l|}{ Brain } \\
\hline \multicolumn{12}{|l|}{ Day 70} \\
\hline Normal $\mathrm{Fe}$ & 0.097 & 0.010 & 0.092 & 0.019 & 0.091 & 0.032 & 0.089 & 0.019 & NS & NS & \multirow[b]{2}{*}{ NS } \\
\hline Fe overload & 0.125 & 0.012 & 0.130 & 0.025 & 0.129 & 0.026 & 0.123 & 0.032 & NS & NS & \\
\hline \multicolumn{12}{|l|}{ Day 90} \\
\hline Normal Fe & 0.099 & 0.012 & 0.101 & 0.021 & 0.101 & 0.025 & 0.102 & 0.021 & NS & NS & \multirow{2}{*}{ NS } \\
\hline Fe overload & 0.122 & 0.017 & 0.118 & 0.010 & 0.119 & 0.022 & 0.125 & 0.051 & NS & NS & \\
\hline \multicolumn{12}{|l|}{ Erythrocytes } \\
\hline \multicolumn{12}{|l|}{ Day 70} \\
\hline Normal Fe & $0.850^{\mathrm{a}}$ & 0.026 & $0.868^{A}$ & 0.036 & $0.681^{b}$ & 0.036 & $0.620^{\mathrm{B}}$ & 0.040 & $<0.001$ & NS & \multirow{2}{*}{$<0.001$} \\
\hline Fe overload & $1.083^{\star}$ & 0.015 & $0.962^{*}$ & 0.023 & $1.075^{\star}$ & 0.032 & $0.986^{*}$ & 0.026 & NS & NS & \\
\hline \multicolumn{12}{|l|}{ Day 90} \\
\hline Normal Fe & $0.622^{\mathrm{a}}$ & 0.018 & $0.595^{A}$ & 0.017 & $0.739^{b}$ & 0.034 & $0.778^{\mathrm{B}}$ & 0.029 & $<0.001$ & NS & \multirow[b]{2}{*}{$<0.001$} \\
\hline Fe overload & $0.977^{\star}$ & 0.020 & $0.918^{\star}$ & 0.027 & $0.928^{*}$ & 0.022 & $0.869^{*}$ & 0.015 & NS & NS & \\
\hline
\end{tabular}

a,b Mean values within a row with unlike superscript letters were significantly different among the groups of control rats $(P<0.05 ;$ Tukey's test).

${ }^{A}, \mathrm{~B}$ Mean values within a row with unlike superscript letters were significantly different among the groups of anaemic rats $(P<0.05 ;$ Tukey's test).

* Mean values were significantly different for the corresponding group of rats fed with normal Fe content $(P<0.05$; Student's $t$ test). 
Table 3. Glutathione peroxidase ( $\mathrm{mmol} / \mathrm{mg}$ protein per $\mathrm{ml}$ ) in the cytosolic fractions of liver, brain and erythrocytes from control and anaemic rats fed the cow or goat milk-based diets, with normal iron content or iron overload, on days 70 and 90 of the study

(Mean values with their standard errors)

\begin{tabular}{|c|c|c|c|c|c|c|c|c|c|c|c|}
\hline \multirow{3}{*}{$\begin{array}{l}\text { Day of the study, tissue and } \\
\text { Fe content in the diet }\end{array}$} & \multicolumn{4}{|c|}{ Cow milk-based diet $(n 80)$} & \multicolumn{4}{|c|}{ Goat milk-based diet ( $n 80)$} & & & \\
\hline & \multicolumn{2}{|c|}{$\begin{array}{l}\text { Control group } \\
\quad(n 40)\end{array}$} & \multicolumn{2}{|c|}{$\begin{array}{l}\text { Anaemic group } \\
\quad(n 40)\end{array}$} & \multicolumn{2}{|c|}{$\begin{array}{l}\text { Control group } \\
(n 40)\end{array}$} & \multicolumn{2}{|c|}{$\begin{array}{l}\text { Anaemic group } \\
(n 40)\end{array}$} & \multicolumn{3}{|c|}{$P$ (one-way ANOVA) } \\
\hline & Mean & SEM & Mean & SEM & Mean & SEM & Mean & SEM & Diet & Anaemia & Fe overload \\
\hline \multicolumn{12}{|l|}{ Liver } \\
\hline \multicolumn{12}{|l|}{ Day 70} \\
\hline Normal Fe & 0.857 & 0.039 & 0.822 & 0.037 & 0.885 & 0.032 & 0.862 & 0.042 & NS & NS & \multirow[b]{2}{*}{$<0.001$} \\
\hline Fe overload & $0.315^{a *}$ & 0.024 & $0.343^{A_{*}}$ & 0.032 & $0.485^{\mathrm{b} *}$ & 0.064 & $0.453^{\mathrm{B} *}$ & 0.045 & $<0.01$ & NS & \\
\hline \multicolumn{12}{|l|}{ Day 90} \\
\hline Normal Fe & 0.390 & 0.025 & 0.397 & 0.025 & 0.369 & 0.015 & 0.380 & 0.014 & NS & NS & \multirow[b]{2}{*}{ NS } \\
\hline Fe overload & 0.341 & 0.024 & $0.416^{\mathrm{A}}$ & 0.023 & 0.350 & 0.012 & $0.396^{\mathrm{B}}$ & 0.018 & NS & NS & \\
\hline \multicolumn{12}{|l|}{ Brain } \\
\hline \multicolumn{12}{|l|}{ Day 70} \\
\hline Normal Fe & $0.261^{a}$ & 0.012 & $0.242^{A}$ & 0.017 & $0.336^{\mathrm{b}}$ & 0.020 & $0.345^{\mathrm{B}}$ & 0.007 & $<0.01$ & NS & \multirow[b]{2}{*}{ NS } \\
\hline Fe overload & $0.271^{a}$ & 0.025 & $0.259^{A}$ & 0.039 & $0.335^{\mathrm{b}}$ & 0.029 & $0.333^{\mathrm{B}}$ & 0.070 & $<0.01$ & NS & \\
\hline \multicolumn{12}{|l|}{ Day 90} \\
\hline Normal Fe & 0.371 & 0.026 & 0.334 & 0.023 & 0.321 & 0.019 & 0.389 & 0.028 & NS & NS & \multirow{2}{*}{ NS } \\
\hline Fe overload & 0.342 & 0.023 & 0.350 & 0.027 & 0.315 & 0.020 & 0.349 & 0.014 & NS & NS & \\
\hline \multicolumn{12}{|l|}{ Erythrocytes } \\
\hline \multicolumn{12}{|l|}{ Day 70} \\
\hline Normal Fe & 1.088 & 0.023 & $1 \cdot 175$ & 0.023 & 1.135 & 0.042 & 1.189 & 0.024 & NS & NS & \multirow{2}{*}{$<0.01$} \\
\hline Fe overload & $0.645^{a *}$ & 0.028 & $0.860^{A \star}$ & 0.020 & $1.070^{\mathrm{b}}$ & 0.030 & $1.085^{\mathrm{B}}$ & 0.029 & $<0.001$ & NS & \\
\hline \multicolumn{12}{|l|}{ Day 90} \\
\hline Normal Fe & 0.685 & 0.040 & 0.720 & 0.045 & 0.722 & 0.022 & 0.715 & 0.024 & NS & NS & \multirow[b]{2}{*}{ NS } \\
\hline Fe overload & $0.614^{a}$ & 0.026 & $0.650^{\mathrm{A}}$ & 0.020 & $0.745^{\mathrm{b}}$ & 0.019 & $0.740^{\mathrm{B}}$ & 0.033 & $<0.001$ & NS & \\
\hline
\end{tabular}

${ }^{a, b}$ Mean values within a row with unlike superscript letters were significantly different among the groups of control rats $(P<0.05$; Tukey's test).

${ }^{A}, \mathrm{~B}$ Mean values within a row with unlike superscript letters were significantly different among the groups of anaemic rats $(P<0.05$; Tukey's test)

${ }^{*}$ Mean values were significantly different for the corresponding group of rats fed with normal Fe content $(P<0.05$; Student's $t$ test).

enzymes, including a number of key enzymes of neurotransmitter biosynthesis in the brain ${ }^{(39)}$. The brain is unique among all the organs of the body, hidden behind a relatively poorly permeable vascular barrier, which limits the access to plasma nutrients, such as $\mathrm{Fe}^{(40)}$. The mechanism of Fe transport into the brain is still uncertain. Endothelial cells make up the blood-brain barrier and express transferrin receptor 1 on the luminal side of the capillaries. These receptors do not modify their expression of transferrin receptor 1 in $\mathrm{Fe}$ deficiency or overload $^{(41)}$; therefore, we can conclude that the nervous system is relatively independent of Fe variations in the organism, at least during the period of the present study, because, as we have examined, it is slightly affected by both Fe overload and anaemia in view of the practically unaltered activities of antioxidant enzymes in both periods of the study.

On days 70 and 90 of the study, an increase in TBARS levels was found in animals fed the Fe-overloaded diets, compared with those fed the normal-Fe diets (Table 4). The generation of superoxide ions, one of the more harmful free radicals, is eight times higher in a situation of $\mathrm{Fe}$ overload than in the absence of this condition ${ }^{(42)}$. In addition,

Table 4. Thiobarbituric acid-reactive substances ( $\mathrm{nmol} / \mathrm{mg}$ protein) in the plasma of control and anaemic rats fed the cow or goat milk-based diets, with normal iron content or iron overload, on days 70 and 90 of the study

(Mean values with their standard errors)

\begin{tabular}{|c|c|c|c|c|c|c|c|c|c|c|c|}
\hline \multirow{3}{*}{$\begin{array}{l}\text { Day of the study and Fe } \\
\text { content in the diet }\end{array}$} & \multicolumn{4}{|c|}{ Cow milk-based diet $(n 80)$} & \multicolumn{4}{|c|}{ Goat milk-based diet $(n 80)$} & & & \\
\hline & \multicolumn{2}{|c|}{$\begin{array}{l}\text { Control group } \\
(n 40)\end{array}$} & \multicolumn{2}{|c|}{$\begin{array}{l}\text { Anaemic group } \\
(n 40)\end{array}$} & \multicolumn{2}{|c|}{$\begin{array}{l}\text { Control group } \\
\quad(n 40)\end{array}$} & \multicolumn{2}{|c|}{$\begin{array}{l}\text { Anaemic group } \\
\quad(n 40)\end{array}$} & \multicolumn{3}{|c|}{$P$ (one-way ANOVA) } \\
\hline & Mean & SEM & Mean & SEM & Mean & SEM & Mean & SEM & Diet & Anaemia & Fe overload \\
\hline \multicolumn{12}{|l|}{ Day 70} \\
\hline Normal Fe & 3.23 & 0.15 & 2.95 & 0.23 & 2.96 & 0.28 & 3.04 & 0.20 & NS & NS & \multirow{3}{*}{$<0.01$} \\
\hline Fe overload & $5 \cdot 72^{a *}$ & 0.59 & $5 \cdot 25^{A *}$ & 0.16 & $3.77^{\mathrm{b}}$ * & 0.25 & $3.95^{\mathrm{B} *}$ & 0.39 & $<0.001$ & NS & \\
\hline \multicolumn{11}{|l|}{ Day 90} & \\
\hline Normal Fe & $5 \cdot 30$ & 0.47 & 4.99 & 0.31 & 4.67 & 0.21 & 4.59 & 0.18 & NS & NS & \multirow{2}{*}{$<0.01$} \\
\hline Fe overload & $7 \cdot 95^{a *}$ & 0.53 & $7.85^{\mathrm{A} *}$ & 0.55 & $6 \cdot 01^{b *}$ & 0.50 & $6 \cdot 11^{\mathrm{B} *}$ & 0.41 & $<0.01$ & NS & \\
\hline
\end{tabular}

${ }_{\mathrm{a}, \mathrm{b}}$ Mean values within a row with unlike superscript letters were significantly different among the groups of control rats $(P<0.05 ;$ Tukey's test).

$\mathrm{A}, \mathrm{B}$ Mean values within a row with unlike superscript letters were significantly different among the groups of anaemic rats $(P<0.05 ;$ Tukey's test).

${ }^{*}$ Mean values were significantly different for the corresponding group of rats fed with normal Fe content $(P<0.05$; Student's $t$ test). 
Linpisarn et al. ${ }^{(43)}$ found very high levels of TBARS in the plasma and tissues of rats after a single dose of intravenous Fe. Later, other authors ${ }^{(5)}$ have reported an increase in TBARS production after the stimulus induced by $\mathrm{H}_{2} \mathrm{O}_{2}$. Taking into account the effect of $\mathrm{Fe}$ as a catalyst of Fenton and Haber-Weiss chemistry and its influence on lipid peroxidation, this result was expected. Nevertheless, this increase is more pronounced in animals receiving the cow milk-based diet that in those fed the goat milk-based diet $(P<0.001$ and $P<0.05$, respectively). This lower trend to prevent lipid peroxidation in animals fed the goat milk-based diet can be due to the beneficial nutritional characteristics of this type of milk that increases the bioavailability of antioxidant minerals, such as $\mathrm{Zn}^{(28,29)}$. Several metals may interact with $\mathrm{Zn}$ in biological systems, and this interaction could have beneficial effects, preventing undesirable Fe-mediated damage, so $\mathrm{Zn}$ can replace $\mathrm{Fe}$ and reduce oxidation in the plasma membrane. Moreover, $\mathrm{Zn}$ could avoid lipid peroxidation in erythrocytes ${ }^{(44)}$ because this mineral competes with Fe for binding sites on the cell membrane ${ }^{(30)}$.

On the other hand, the better nutritive utilisation of goat milk fat ${ }^{(10)}$ provides a lower substrate for lipid peroxidation and consequently decreases the generation of free radicals in animals consuming this type of milk, explaining once more the lower TBARS levels found in the groups consuming the goat milk-based diets.

TBARS levels increased at day 90 compared with day 70 $(P<0.001)$, which could be due to the fact that all the processes of lipid peroxidation are intimately related to the age. The generation of free radicals and subsequently the related processes of lipid peroxidation are more significant as the life of the animal increases ${ }^{(45)}$, which explains why TBARS are higher at the end of the experimental period (day 90; Table 4), since at this stage, the animal has evolved from a juvenile condition, where growth is very active (the phase of rapid physical and mental development), to the adult stage of maturity, where development has stopped ${ }^{(46,47)}$. In addition, as was expected, the lipid peroxidation processes are higher in a situation of chronic Fe overload, due to the increased generation of free radicals and the consequent damage to fatty acids ${ }^{(4)}$

In summary, habitual goat milk consumption, a natural food with excellent nutritional characteristics, has positive effects on enzymatic antioxidant defence, even in a situation of $\mathrm{Fe}$ overload, which limits the processes of lipid peroxidation in comparison with cow milk consumption. Therefore, it would be recommendable to include this type of milk in the habitual diet, in the general population and in those affected by nutritional Fe-deficiency anaemia, especially in those consuming oral supplements of $\mathrm{Fe}$, given the high prevalence of this pathology worldwide and because Fe overload is a common consequence of its treatment.

\section{Acknowledgements}

This study was funded by the Inter-Ministerial Commission of Science and Technology Research Project no. AGL-200602301/ALI. The authors are grateful to Lactalis Iberia, S.A.
(Lugo, Spain) for providing the dairy products used in the present study, the University of Granada for the personal support of J. D.-C. and Elisa Alcover for her efficient administrative support. M. S. C. designed and conducted the study, analysed the data and wrote the manuscript; J. D.-C., I. L.-A., M. J. M. A., T. N. and L. J. P.-S. performed the experiments, data collection, statistical analysis and wrote the manuscript. M. R. L.-F. and M. L. O. collaborated in the enzyme analysis. All authors declare that they have no conflicts of interest.

\section{References}

1. Muñoz M, Villar I \& García-Erce JA (2009) An update on iron physiology. World J Gastroenterol 15, 4617-4626.

2. Kaushansky K (2006) Lineage-specific hematopoietic growth factors. $N$ Engl J Med 354, 2034-2045.

3. Halliwell B \& Gutteridge JMC (1990) Role of free radicals and catalytic metal ions in human disease. In Oxygen Radicals, pp. 1-85 [L Packer, editor]. San Diego, CA: Academic Press.

4. Aust AE \& Eveleigh JF (1999) Mechanisms of DNA oxidation. Proc Soc Exp Biol Med 222, 246-252.

5. Vives Corrons JL, Miguel-Garcia A, Pujades MA, et al. (1995) Increased susceptibility of microcytic red blood cells to in vitro oxidative stress. Eur J Haematol 55, 327-331.

6. Kumerova A, Lece A, Skesters A, et al. (1998) Anaemia and antioxidant defence of the red blood cells. Mater Med Pol 30, 2-5.

7. Aslan M, Horoz M, Kocyigit A, et al. (2006) Lymphocyte DNA damage and oxidative stress in patients with iron deficiency anemia. Mutat Res 601, 144-149.

8. Díaz-Castro J, Alférez MJM, López-Aliaga I, et al. (2008) Influence of nutritional iron deficiency anemia on DNA stability and lipid peroxidation in rats. Nutrition 24, 1167-1173.

9. Brandsch C, Ringseis R \& Eder K (2002) High dietary iron concentrations enhance the formation of cholesterol oxidation products in the liver of adult rats fed salmon oil with minimal effects on antioxidant status. J Nutr 132, 2263-2269.

10. Alférez MJM, Barrionuevo M, López-Aliaga I, et al. (2001) Digestive utilization of goat and cow milk fat in malabsorption syndrome. J Dairy Res 68, 451-461.

11. Nestares T, Díaz-Castro J, Alférez MJM, et al. (2008) Calciumenriched goats' milk aids recovery of iron status better than calcium-enriched cows' milk, in rats with nutritional ferropenic anaemia. J Dairy Res 75, 153-159.

12. Reeves PG, Nielsen FH \& Fahey GC (1993) AIN-93 purified diets for laboratory rodents: final report of the American Institute of Nutrition and $A d H o c$ Writing Committee on the reformulation of the AIN-76A rodent diet. J Nutr $\mathbf{1 2 3}$, 1939-1951.

13. Pallarés I, Lisbona F, López-Aliaga I, et al. (1993) Effects of iron deficiency on the digestive utilization of iron, phosphorus, calcium and magnesium in rats. Br J Nutr $\mathbf{7 0}$, 609-620.

14. Hanahan DJ \& Ekholm JE (1974) The preparation of red cell ghosts (membranes). Meth Enzymol 31, 168-172.

15. Lowry OH, Rosenburgh NJ, Farr AL, et al. (1951) Protein measurement with folin phenol reagent. J Biol Chem 193, $265-270$.

16. Raja KB, Simpson RJ \& Peters TJ (1994) Intestinal iron absorption studies in mouse models of iron-overload. $\mathrm{Br} \mathrm{J}$ Haematol 86, 156-162.

17. Flohé L \& Günzler WA (1984) Assays of glutathione peroxidase. Meth Enzymol 105, 114-121. 
18. Crapo JD, McCord JM \& Fridovich I (1978) Preparation and assay of superoxide dismutases. Meth Enzymol 53, 382-393.

19. Aebi H (1984) Catalase in vitro. Meth Enzymol 150, 121-127.

20. Yagi K (1976) A simple fluorometric assay for lipoperoxide in blood plasma. Biochem Med 15, 212-216.

21. Ohkawa H, Ohishi N \& Yagi K (1979) Assay for lipid peroxides in animal tissues by thiobarbituric acid reaction. Anal Biochem 95, 351-358.

22. Acharya J, Punchard NA, Taylor IA, et al. (1991) Red cell peroxidation and antioxidant enzymes in iron deficiency. Eur J Haematol 47, 287-291.

23. Isler M, Delibas N, Guclu M, et al. (2002) Superoxide dismutase and glutathione peroxidase in erythrocytes of patients with iron deficiency anemia: effects of different treatment modalities. J Croat Med 43, 16-19.

24. Tanaka N \& Kiyosawa A (2004) Phlebotomy: a promising treatment for chronic hepatitis C. I Gastroenterol 39, 601-603.

25. Hess SY, Zimmermann MB, Arnold M, et al. (2002) Irondeficiency anemia reduces thyroid peroxidase activity in rats. J Nutr 132, 1951-1955.

26. Ghone RA, Kumbar KM, Suryakar AN, et al. (2008) Oxidative stress and disturbance in antioxidant balance in beta thalassemia major. Indian J Clin Biochem 23, 337-340.

27. Sahin E \& Gümüşlü S (2007) Stress-dependent induction of protein oxidation, lipid peroxidation and anti-oxidants in peripheral tissues of rats: comparison of three stress models (immobilization, cold and immobilization-cold). Clin Exp Pharmacol Physiol 34, 425-431.

28. Alférez MJM, López-Aliaga I, Barrionuevo M, et al. (2003) Effect of dietary inclusion of goat milk on the bioavailability of zinc and selenium in rats. J Dairy Res 70, 181-187.

29. Díaz-Castro J, Alférez MJM, López-Aliaga I, et al. (2009) Effect of calcium-supplemented goat or cow milk on zinc status in rats with nutritional ferropenic anaemia. Int Dairy J 19, 116-121.

30. Zago MP \& Oteiza PI (2001) The antioxidant properties of zinc: interactions with iron and antioxidants. Free Radic Biol Med 31, 266-274.

31. Chen OS, Schalinske KL \& Eisenstein RS (1997) Dietary iron intake modulates the activity of iron regulatory proteins and the abundance of ferritin and mitochondrial aconitase in rat liver. J Nutr 127, 238-248.

32. Feder JN, Penny DM, Irrinki A, et al. (1998) The haemochromatosis gene product complexes with the transferrin receptor and lowers its affinity for ligand binding. Proc Natl Acad Sci U S A 95, 1472-1477.

33. Breuer W, Hershko C \& Cabantchik ZI (2000) The importance of non-transferrin bound iron in disorders of iron metabolism. Transfus Sci 23, 185-192.

34. Hider RC (2002) Nature of nontransferrin-bound iron. Eur J Clin Invest 32, 50-54.

35. Esposito BP, Breuer W, Sirankapracha P, et al. (2003) Labile plasma iron in iron overload: redox activity and susceptibility to chelation. Blood 102, 2670-2677.

36. Weinstein DA, Roy CN, Fleming MD, et al. (2002) Inappropriate expression of hepcidin is associated with iron refractory anemia: implications for the anemia of chronic disease. Blood 100, 3776-3781.

37. Ben-Assa E, Youngster I, Kozer E, et al. (2009) Changes in serum hepcidin levels in acute iron intoxication in a rat model. Toxicol Lett 189, 242-247.

38. Siah CW, Ombiga J, Adams LA, et al. (2006) Normal iron metabolism and the pathophysiology of iron overload disorders. Clin Biochem Rev 27, 5-16.

39. Crichton RR, Danielsson BG \& Geisser P (2008) Iron metabolism: biologic and molecular aspects. In Iron Therapy with Special Emphasis on Intravenous Administration, 4th ed., pp. 14-24 [RR Crichton, BG Danielsson and P Geisser, editors]. Bremen: UNI-Med Verlag AG.

40. Crichton RR, Dexter DT \& Ward RJ (2011) Brain iron metabolism and its perturbation in neurological diseases. J Neural Transm 118, 301-314.

41. Moos T, Rosengren Nielsen T, Skjørringe T, et al. (2007) Iron trafficking inside the brain. I Neurochem 103, 1730-1740.

42. Scott MD, VanDer Berg JJM \& Repka T (1993) Effect of excess $\alpha$-hemoglobin chains on cellular and membrane oxidation in model beta-thalassemic erythrocytes. J Clin Invest 91, 1706-1712.

43. Linpisarn S, Satoh K, Maikami T, et al. (1991) Effects of iron on lipid peroxidation. Int J Hematol 54, 181-188.

44. Girotti AW, Thomas JP \& Jordan JE (1985) Inhibitory effect of $\mathrm{Zn}$ (II) on free radical lipid peroxidation in erythrocyte membranes. Free Radic Biol Med 1, 395-401.

45. Jacob MH, Janner DR, Jahn MP, et al. (2010) Age-related effects of DHEA on peripheral markers of oxidative stress. Cell Biochem Funct 28, 52-57.

46. Sisk CL \& Zehr JL (2005) Pubertal hormones organize the adolescent brain and behaviour. Front Neuroendocrinol 26, $163-174$.

47. McCutcheon JE \& Marinelli M (2009) Age matters. Eur J Neurosci 29, 997-1014. 